\title{
Learning and memory ... and the immune system
}

\author{
loana Marin and Jonathan Kipnis ${ }^{1}$ \\ Center for Brain Immunology and Glia (BIG), Department of Neuroscience, Neuroscience Graduate Program, School of Medicine, \\ University of Virginia, Charlottesville, Virginia 22908, USA
}

\begin{abstract}
The nervous system and the immune system are two main regulators of homeostasis in the body. Communication between them ensures normal functioning of the organism. Immune cells and molecules are required for sculpting the circuitry and determining the activity of the nervous system. Within the parenchyma of the central nervous system (CNS), microglia constantly monitor synapses and participate in their pruning during development and possibly also throughout life. Classical inflammatory cytokines, such as interleukin (IL)-1 $1 \beta$ and tumor necrosis factor (TNF), are released during neuronal activity and play a crucial role in regulating the strength of synaptic transmission. Systemically, proper functioning of the immune system is critical for maintaining normal nervous system function. Disruption of the immune system functioning leads to impairments in cognition and in neurogenesis. In this review we provide examples of the communication between the nervous and the immune systems in the interest of normal CNS development and function.
\end{abstract}

The nervous system is universally perceived as the command center of the body. Sensory organs and peripheral nerve fibers monitor the external environment, while chemical changes in the internal environment are monitored by their receptors in the brain. The nervous system can therefore be viewed as the master regulator of homeostasis. In this role, however, it does not act alone. The immune system, through its tissue-resident and patrolling immune cells, also operates constantly to monitor the internal environment and maintain overall balance in the body. Immune cells respond not only to infection, but also to tissue damage and stress, and in addition they clear cellular debris that results from physiological cell death.

Although collaboration between the two systems was long regarded as unlikely because of their separation by the bloodbrain barrier (BBB), it is now known that such collaboration does occur, and moreover that it is essential for the body's normal functioning. It could be argued that the $\mathrm{BBB}$ evolved to protect the nervous system from toxins and pathogens, not to isolate the brain from other systems. Not only are the immune and the nervous systems physically connected-there are resident immune cells in the central nervous system (CNS) and peripheral nerve terminals in immune organs-they also share each other's "languages" for their communication. Thus, cells of the nervous system can use signaling by immune components, such as cytokines and chemokines, to communicate with each other (Steinman 2004; McAllister and van de Water 2009; Ben MenachemZidon et al. 2011; Diaz Heijtz et al. 2011; Gabay et al. 2011; Yirmiya and Goshen 2011), while immune cells possess neurotransmitter receptors and can synthesize neurotransmitter molecules including acetylcholine, glutamate, dopamine, and serotonin (Koval et al. 1997; Steinman 2004; Ganea et al. 2006; Pocock and Kettenmann 2007; Levite 2008; Kong et al. 2010; Patterson 2012).

Despite increasing evidence for amicable relations between the nervous system and immune cells, most of our knowledge about neuroimmune interactions comes, not surprisingly, from studies using models of infection, injury, or autoimmunity (Dantzer et al. 2000, 2008; Steinman 2004; Aaltonen et al. 2005; Huang et al. 2008; O'Connor et al. 2009; Yirmiya and Goshen 2011;

\footnotetext{
${ }^{1}$ Corresponding author Email kipnis@virginia.edu

Article is online at http://www.learnmem.org/cgi/doi/10.1101/Im.028357.112.
}

Shechter et al. 2013a). In many of these models, inflammation is associated with sickness behavior and infiltration of peripheral immune cells into the CNS with pathological results. Over the past two decades, however, an accumulating body of research has pointed to neuroimmune interactions as primarily beneficial, in that they promote homeostasis of the nervous system (Kipnis et al. 2004, 2008, 2012; Cohen et al. 2006; Ziv et al. 2006; Brynskikh et al. 2008; Derecki et al. 2010).

Here we present a neurocentric review of the roles played by immune cells and molecules in supporting the development and function of the nervous system under normal physiological conditions.

\section{Brain-resident immune cells-the microglia}

When considering brain/immune interactions, one must recognize that the microglia, although a type of immune cell, are a constitutive part of the nervous system (Ransohoff and Cardona 2010). Microglia originate from primordial macrophages in the yolk sac, which in mice migrate out around E7.5 and invade the neural tube on E10.5 (Ginhoux et al. 2010; Hooper et al. 2012), before the BBB is formed.

Microglia serve important functions during embryonic development-not only in clearing the apoptotic debris resulting from the intensive cell turnover, but also in promoting neuronal apoptosis (Marin-Teva et al. 2004; Sierra et al. 2010; Wang et al. 2012). A more subtle yet equally important function of the microglia in shaping neuronal circuitry is the pruning of synaptic spines. Microglia engulf presynaptic termini, contributing to the adult cortical architecture (Paolicelli et al. 2011; Schafer et al. 2012). This synaptic pruning is dependent on components of the complement system, which is one of the immune system's activating pathways. Synaptic pruning by microglia was first demonstrated in the developing lateral geniculate nucleus (LGN) (Stevens et al. 2007). Barres, Stevens, and colleagues (Stevens et al. 2007) showed that the entire classical complement cascade is up-regulated when ocular input segregation occurs during early postnatal development. Neuronal-derived C1q activates a signaling cascade that ultimately culminates in activation of the C3R complement receptor on microglia, and these cells then preferentially engulf inactive synapses (Schafer et al. 2012). Genetic deletion of any of the components of this complement cascade leads to deficits in ocular dominance territories in the LGN. 
Another signaling system that participates in synaptic pruning by microglia requires the neural cell-secreted chemokine CX3CL1 (fraktalkine) and its cognate receptor on microglia. Fraktalkine is enriched in the brain compared to any other organ in the body (Harrison et al. 1994), while its receptor, CX3CR1, is strongly expressed on microglia (Gautier et al. 2012), underlying the importance of this signaling pathway in the brain. Furthermore, CX3CR1-deficient mice show deficits in hippocampal synaptic pruning during early postnatal development (P15). However, these deficits are apparently resolved by adulthood through other mechanisms as yet unknown (Paolicelli et al. 2011). Moreover, CX3CR1-deficient microglia demonstrate delayed recruitment to the developing barrel cortex, with a corresponding delay in maturation of the postsynaptic compartment in terms of the AMPA/NMDA receptor ratio as well as the subunit composition of NMDA receptors (Hoshiko et al. 2012). Although these developmental aspects appear to achieve resolution, adult CX3CR1-knockout mice still exhibit deficits indicative of malfunctioning circuitry. Rogers et al. (2011) showed that these mice demonstrate impaired learning, probably accompanied by an inability to achieve long-term potentiation (LTP) in the hippocampus. The authors also showed that, compared with wildtype controls, the proinflammatory cytokine interleukin (IL)- $1 \beta$ in the CX3CR1-knockout mouse hippocampus is significantly increased. Increased IL-1 $\beta$ levels might be a cause of the impaired LTP, since administration of the IL-1 receptor antagonist IL-1Ra restored LTP in hippocampal slices from these mutant mice.

It is not clear whether the process of synapse engulfment is maintained in adulthood, but "resting" microglial processes have been shown to continuously contact synapses (Nimmerjahn 2005; Wake et al. 2009; Tremblay et al. 2010). The probability of contact is activity-dependent, with inactive synapses being contacted less frequently (Wake et al. 2009). A different study indicated that microglia may also preferentially contact smaller synapses that are subsequently lost (Tremblay et al. 2010). Studies in vitro (Aarum et al. 2003; Butovsky et al. 2006) have shown that microglia, or their conditioned media, are beneficial for neurogenesis, the differentiation of neural progenitor cells into neurons, or for both. Further study is needed, however, in order to investigate the in vivo relevance of these findings. Mice deficient in CX3CR1 signaling show deficits in adult neurogenesis in the dentate gyrus (Paolicelli et al. 2011), indicating that communication between neurons and microglia is necessary for maintaining homeostatic functioning of the neurogenic niche.

\section{Immune molecules provide a service to the brain}

Neuronal expression of the major histocompatibility complex class I (MHCI) was first shown by the group led by Carla Shatz in 1998 (Corriveau et al. 1998). Prior to that, the prevailing view was that neurons were among the few cell types in the body that do not express MHCI, a complex molecule responsible for the cellspecific signature of its expressed proteins and thus crucial for the immune system to separate self from nonself. Several isotypes of this molecular complex are now known to be expressed by neurons in the thalamus, hippocampus, cortex, and cerebellum, along with the accessory molecules $\mathrm{CD} 3 \zeta$ and $\beta 2$-microglobulin. MHCI staining appears as puncta at synapses and colocalizes with postsynaptic density protein 95 (PSD95) (Goddard et al. 2007; Datwani et al. 2009). Knockout MHCI $\left(\mathrm{KbDb}^{-/-}\right)$mice exhibit a phenotype similar to that of the C1q-deficient mice, showing reduced segregation of ocular inputs in the LGN (Datwani et al. 2009). Compared to wild-type controls, MHCI knockout neurons also show enhanced synaptic plasticity and increased excitability, and exhibit higher frequency of miniature excitatory postsynaptic currents (mEPSCs) in the hippocampus, as well as heightened LTP and decreased long-term depression (LTD) (Huh et al. 2000; Goddard et al. 2007). All of these findings point to an important role for the molecules originally defined as "immune" in higher brain function. In vivo, $\mathrm{KbDb}^{-/-}$mice show superior motor learning, probably as a result of decreased threshold for LTD at the inhibitory synapses of parallel fibers (McConnell et al. 2009). An interesting finding was that PirB, a known receptor for MHCI in the brain, is also expressed on neurons, and that PirB-deficient mice show increased plasticity in the visual cortex, raising speculation about neuron-neuron signaling through MHCI/PirB-modulating neuronal activity (Syken et al. 2006).

Another class of immune molecules involved in the proper functioning of the nervous system is represented by cytokines. The source of cytokine secretion was originally traced to immune cells, which employ these molecules as messengers, triggers, and effectors of immune responses. Despite their great functional diversity, cytokines in the nervous system have earned an unfortunate reputation through their observed association with inflammation or sickness behavior (Kelley et al. 2003; Dantzer et al. 2008; Godbout et al. 2008; Huang et al. 2008). Studies investigating the role of inflammation in aging or pathologye.g., inflammation/infection, neurodegeneration, depressionare numerous and have been reviewed extensively by others (Lucin and Wyss-Coray 2009; von Bernhardi et al. 2010; Kohman and Rhodes 2013; McCusker and Kelley 2013). On the other hand, the literature regarding the role of cytokines in homeostatic brain function is slower to accumulate. Several studies have shown, however, that cytokines such as tumor necrosis factor (TNF) and IL-1 $\beta$, once considered to be purely inflammatory, are produced in the brain under normal conditions and are crucial for normal synaptic functioning (Wolf et al. 2008; Goshen and Yirmiya 2009; Ben Menachem-Zidon et al. 2011; Yirmiya and Goshen 2011).

TNF signaling through the TNF receptor TNFR1 (but not through TNFR2) modulates synaptic strength by changing the expression of AMPA receptors (AMPAR) in the postsynaptic compartment (Dummer et al. 2002). TNFR1-knockout neurons exhibit decreased expression of AMPAR and correspondingly decreased postsynaptic transmission. On the other hand, exogenous application of TNF was found to increase AMPAR expression, as well as the frequency and amplitude of mEPSCs (Beattie et al. 2002; Stellwagen and Malenka 2006). Subsequently, glia-secreted TNF was identified as an important factor in mediating synaptic scaling (Stellwagen and Malenka 2006). Following the blockade of neuronal activity by application of the neurotoxin tetrodotoxin, postsynaptic compartments become more sensitive and the frequencies of mEPSCs are increased. In neurons cultured with TNF-knockout astrocytes, however, this effect is not observed (Stellwagen and Malenka 2006). Moreover, in monocular deprivation (an in-vivo model of visual plasticity), TNF-knockout mice display the expected diminished responses to the deprived eye, but not the correspondingly increased responses to the open eye (Kaneko et al. 2008). TNF also seems to play a role in adult hippocampal neurogenesis. Iosif and colleagues (2006) showed that progenitors in the subgranular zone express both TNF and its receptors TNFR1 and TNFR2, and that their genetic knockout differentially affects adult neurogenesis: signaling through TNFR1 seems to act as a negative regulator of neurogenesis, as its deletion results in an increase in the number of newly produced neurons, whereas TNFR2 signaling is a positive regulator, as indicated by the drop in neurogenesis following its deletion.

IL-1 $\beta$, another proinflammatory cytokine, is up-regulated during LTP induction in hippocampal slices and is evidently necessary for the maintenance of this potentiation, since application of the IL-1 $\beta$ receptor antagonist, IL-1Ra, leads to unsustained LTP 
(Schneider et al. 1998). Moreover, expression of a related protein, IL- $1 \alpha$, when signaling through the same receptor, is even more robustly up-regulated during LTP protocols (Ross et al. 2003). The importance of signaling through the IL1 receptor for learning was validated in vivo using several transgenic mouse models with impaired or reduced signaling in this pathway (Avital et al. 2003; Goshen et al. 2007; Spulber et al. 2009). These transgenic mice were found to exhibit impairments in various learning tasks, such as Morris water maze. IL-1R signaling is also evidently important during development, since treatment in utero with the receptor antagonist Il-1Ra leads to cognitive deficits in adulthood (Goshen et al. 2007). On the other hand, studies investigating the consequences of overexpression or direct injection of IL-1 $\beta$ in the brain (Matsumoto et al. 2004; Moore et al. 2009) concluded that an excess of IL-1 $\beta$ leads to memory deficits. Similarly, exogenous application of large amounts (e.g., $10 \mathrm{ng} / \mathrm{mL}$ ) of IL- $1 \beta$ in vitro results in decreased synaptic strength and LTD induction (Ikegaya et al. 2003; Ross et al. 2003). Unfortunately, these last findings have little physiological significance, because concentrations of IL-1 $\beta$ in the brain, even during inflammation, are in the $\mathrm{pg} / \mathrm{mL}$ range (Denes et al. 2011).

The recombination activating gene (RAG) products Rag1 and Rag2 mediate V(D)J recombination, a vital process that takes place in the primary lymphoid tissues of the bone and thymus and is responsible for diversity of T and B cell receptors (Mombaerts et al. 1992). Intriguingly, Rag1 is expressed in the brain both pre- and postnatally, whereas Rag2 seems not to be expressed in the CNS (Chun et al. 1991). Rag1 is critical for V(D)J recombination in lymphocytes (Chun et al. 1991), and Rag1-deficient mice are virtually devoid of mature lymphocytes (T and B cells) (Mombaerts et al. 1992). The functions of Rag1 in the immune system and in the brain are apparently not similar; in fact, its function in the nervous system remains unclear. Nevertheless, both Rag1-deficient and Rag2-deficient mice exhibit cognitive impairments in several social and learning tasks, as well as in adult neurogenesis (Wolf et al. 2009; McGowan et al. 2011). This finding points to a role for the peripheral adaptive immune system in supporting brain function, rather than suggesting a role for Rag1 in the maintenance of CNS homeostasis.

Members of the Toll-like receptor (TLR) family were recently shown to be expressed in the nervous system by all major cell types (Okun et al. 2011). TLRs are a class of pattern recognition receptors expressed on virtually all immune-cell types and known to recognize not only conserved molecular patterns found on pathogens but also endogenous danger signals. Studies on mice deficient in various TLRs have shown that TLR signaling can affect the proper functioning of the nervous system both positively and negatively, though it is not yet possible to conclude whether such maintenance of nervous system activity is a function of signaling in the brain, in the periphery, or both. For example, TLR2knockout mice show impaired differentiation of neural progenitors in the hippocampus, where more neural progenitor cells differentiate into astrocytes than into neurons, pointing to TLR2 as supportive of adult neurogenesis (Rolls et al. 2007). On the other hand, TLR4 signaling seems to be a negative regulator of neurogenesis, as TLR4-deficient mice exhibit increased neural progenitor proliferation in the hippocampus, as well as skewed neuronal differentiation (Rolls et al. 2007). Investigation of the role of TLR3 signaling in cognitive function revealed that TLR3knockout mice show generally better memory performance and less anxiety than their wild-type counterparts (Okun et al. 2010), suggesting that TLR3 signaling may also be a negative regulator of plasticity and learning. All in all, the possible roles of TLRs in supporting nervous system homeostasis are only now beginning to be explored, and more detailed studies are necessary in order to understand the specifics of their functioning.

\section{Brain support by the peripheral immune system}

As indicated by the phenotypes of Rag1-and Rag2-knockout mice, as well as by the plethora of studies of cognitive performance during infection, the state of the peripheral immune system can greatly influence nervous system functioning.

Adult neurogenesis is a process that has been investigated in the context of numerous types of immune system disruptions. The regulatory presence of an adaptive immune system is necessary for maintenance of adult neurogenesis. Mice with severe combined immunodeficiency (SCID) and nude mice, which are deprived, respectively, of all lymphocytes and of T cells, show impairments in neurogenesis, and T-cell replenishment in these mice rescues their phenotype (Ziv et al. 2006). Interestingly, transgenic mice with $\mathrm{T}$ cells specific for the auto-antigen myelin basic protein exhibit increased neurogenesis, whereas neurogenesis in transgenic mice with T cells specific for an irrelevant antigen (ovalbumin) is decreased (Ziv et al. 2006). These observations suggest that specific interactions between the nervous and immune systems contribute to normal brain function. Mast cells, an immune cell classically associated with allergic responses, are also important for supporting adult neurogenesis (Nautiyal et al. 2008, 2012). Mast cells are resident in and around the hippocampus and secrete serotonin. From this location they appear to play a role in maintaining the neurogenic niche, since treatment with fluoxetine, a selective inhibitor of serotonin reuptake, abolishes the differences in neurogenesis between mice deficient in mast cells and their heterozygotic littermates (Nautiyal et al. 2008).

Immune deficiency in mice is often accompanied by cognitive impairment (Kipnis et al. 2004, 2012; Cohen et al. 2006; Ziv et al. 2006; Brynskikh et al. 2008; Lewitus and Schwartz 2009; Derecki et al. 2010; Bailey et al. 2011; Gadani et al. 2012; Nautiyal et al. 2012; Baruch et al. 2013; Radjavi et al. 2013). As with neurogenesis, replenishment of the immune system by adoptive transfer of wild-type splenocytes or by bone marrow reconstitution also improves the learning ability of SCID and nude mice in MWM, Barnes maze and radial arm water maze (Brynskikh et al. 2008; Ron-Harel et al. 2008; Derecki et al. 2010; Bailey et al. 2011). We have recently identified the meningeal membranes surrounding the brain as an important site of the immune response that occurs during learning (Derecki et al. 2010). When mice are exposed to a learning task, $\mathrm{T}$ cells migrate to the meninges and become activated there. In wild-type mice these $\mathrm{T}$ cells acquire a "Th2-like" phenotype (regarded as anti-inflammatory) and express high levels of IL-4. Moreover, the myeloid cells in the meninges become skewed toward an M2 (or alternatively activated, also regarded as tissue building and anti-inflammatory) phenotype. Interference with the migration of T cells, or genetic deletion of $I L-4$, results in a proinflammatory M1 (classically activated and inflammatory [Yirmiya and Goshen 2011]) skew of the myeloid cells in the meninges (Belmaker and Agam 2008; Derecki et al. 2010). In view of these findings, it is tempting to speculate that the adaptive immune system supports cognition by keeping the meningeal innate system in check and preventing inflammation in response to learning-associated stress (Fig. 1). Schwartz and colleagues have also identified the choroid plexus as an important site of neuroimmune interactions (Baruch et al. 2013; Shechter et al. 2013b). Interestingly, the T cell repertoire in the choroid plexus seems to be enriched in CNS-reactive cells (Baruch and Schwartz 2013), leading to the idea that autoimmune cells are important in modulating the nervous system milieu to support homeostasis (Kipnis et al. 2012; Shechter et al. 2013a). This argument is also supported by the fact that transgenic mice with CNSantigen specific $T$ cells also show enhanced cognition, in addition to neurogenesis in subgranular and subventricular zones (Ziv et al. 2006). 


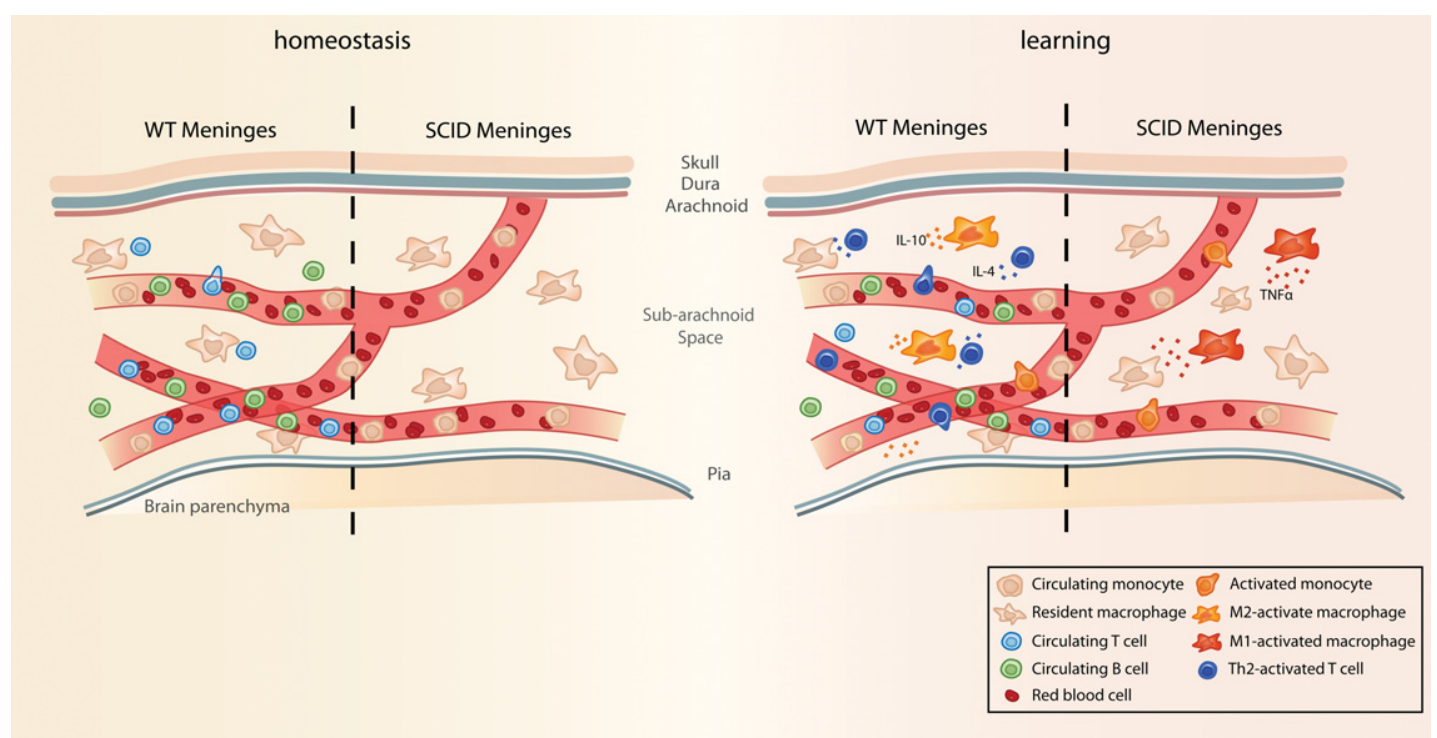

Figure 1. Working model of the immune response during a cognitive task. Under homeostatic conditions, the meningeal spaces are surveyed for potential disturbances by resident myeloid cells, as well as circulating white blood cells (including monocytes and T cells). During an acute cognitive task performance, such as Morris water maze, circulating immune cells can be activated by peripheral danger signals (the identity of which is yet to be determined, but potentially corticosterone and catecholamines), which are released in response to the stress that the task involves. In a wild-type mouse, activated T cells and monocytes infiltrate the meninges and mount a homeostatic type-2 immune response, releasing tissue-building cytokines such as IL-4 and IL-10. In SCID mice that lack the adaptive branch of the immune system (no mature T and B cells), nonregulated inflammatory monocytes initiate a type 1 inflammatory response, with the release of inflammatory cytokines such as TNF $\alpha$. Although the cellular and molecular pathways are yet to be elucidated, the inflammatory type-1 response contributes to impaired cognition, whereas an alternative type- 2 immune response is more "procognitive."

\section{Concluding remarks}

This review presents evidence for the numerous points of communication between the nervous and the immune systems, and focuses on the consequent implication that a normal functioning immune system is critical in supporting cognitive function. The relationship between these systems, however, is a mutual one. All of the body's immune organs are innervated to some degree, and unimpaired neurotransmission is essential for both initiation and termination of immune responses. For example, sympathetic innervation of the bone marrow is required for recruitment of immune cells from the hematopoietic reservoir during infection (Katayama et al. 1990; Spiegel et al. 2007; von Bernhardi et al. 2010). On the other hand, neuronal control through the vagus nerve serves to suppress inflammation in response to endotoxin (Borovikova et al. 2000; Steinman 2004; Pavlov and Tracey 2012). Therefore even when it appears that the nervous system is merely a victim of a flared immune system, the two systems maintain a constant dialogue in the attempt to restore homeostasis.

Although numerous studies now support connections between the nervous and immune systems in models of infection and injury (Steinman 2004; Aaltonen et al. 2005; Yirmiya and Goshen 2011; Benach et al. 2012), large gaps remain with regard to how the two systems interact under normal homeostatic conditions. Most of the evidence for immune support in learning comes from whole-body knockout of certain molecules, making it difficult to distinguish cell-specific or developmental effects. Moreover, more research needs to be devoted to maintenance of the physiological concentrations of tested molecules so that conclusions can be drawn about phenomena in vivo. It often happens that the changes occurring in the body during development or learning are so subtle, and the conditions under which processes are modeled in vitro so extreme, that the relevance of conclusions obtained from in vitro studies is questionable.

\section{Acknowledgments}

We thank Shirley Smith for editing the manuscript. We thank the members of the Kipnis lab for their valuable comments during multiple discussions of this work. This work was primarily supported by a grant from the National Institute on Aging, NIH (AG034113 award to J.K.).

\section{References}

Aaltonen R, Heikkinen T, Hakala K, Laine K, Alanen A. 2005. Transfer of proinflammatory cytokines across term placenta. Obstet Gynecol 106: 802-807.

Aarum J, Sandberg K, Haeberlein SL, Persson MA. 2003. Migration and differentiation of neural precursor cells can be directed by microglia. Proc Natl Acad Sci 100: 15983-15988.

Avital A, Goshen I, Kamsler A, Segal M, Iverfeldt K, Richter-Levin G, Yirmiya R. 2003. Impaired interleukin-1 signaling is associated with deficits in hippocampal memory processes and neural plasticity. Hippocampus 13: 826-834.

Bailey MT, Dowd SE, Galley JD, Hufnagle AR, Allen RG, Lyte M. 2011. Exposure to a social stressor alters the structure of the intestinal microbiota: Implications for stressor-induced immunomodulation. Brain Behav Immun 25: 397-407.

Baruch K, Schwartz M. 2013. CNS-specific T cells shape brain function via the choroid plexus. Brain Behav Immun doi: 10.1016/j.bbi.2013.04.002.

Baruch K, Ron-Harel N, Gal H, Deczkowska A, Shifrut E, Ndifon W, Mirlas-Neisberg N, Cardon M, Vaknin I, Cahalon L, et al. 2013. CNS-specific immunity at the choroid plexus shifts toward destructive Th2 inflammation in brain aging. Proc Natl Acad Sci 110: $2264-2269$.

Beattie EC, Stellwagen D, Morishita W, Bresnahan JC, Ha BK, Von Zastrow M, Beattie MS, Malenka RC. 2002. Control of synaptic strength by glial TNF $\alpha$. Science 295: 2282-2285.

Belmaker R, Agam G. 2008. Major depressive disorder. N Engl J Med 358: 55-68.

Ben Menachem-Zidon O, Avital A, Ben-Menahem Y, Goshen I, Kreisel T, Shmueli EM, Segal M, Ben Hur T, Yirmiya R. 2011. Astrocytes support hippocampal-dependent memory and long-term potentiation via interleukin-1 signaling. Brain Behav Immun 25: 1008-1016.

Benach J, Li E, McGovern M. 2012. A microbial association with autism. mBio 3: doi: 10.1128/mBio.00019-12. 
Borovikova LV, Ivanova S, Zhang M, Yang H, Botchkina GI, Watkins LR, Wang H, Abumrad N, Eaton JW, Tracey KJ. 2000. Vagus nerve stimulation attenuates the systemic inflammatory response to endotoxin. Nature 405: 458-462.

Brynskikh A, Warren T, Zhu J, Kipnis J. 2008. Adaptive immunity affects learning behavior in mice. Brain Behav Immun 22: 861-869.

Butovsky O, Ziv Y, Schwartz A, Landa G, Talpalar AE, Pluchino S, Martino G, Schwartz M. 2006. Microglia activated by IL-4 or IFN- $\gamma$ differentially induce neurogenesis and oligodendrogenesis from adult stem/progenitor cells. Mol Cell Neurosci 31: 149-160.

Chun JJ, Schatz DG, Oettinger MA, Jaenisch R, Baltimore D. 1991. The recombination activating gene-1 (RAG-1) transcript is present in the murine central nervous system. Cell 64: 189-200.

Cohen H, Ziv Y, Cardon M, Kaplan Z, Matar MA, Gidron Y, Schwartz M, Kipnis J. 2006. Maladaptation to mental stress mitigated by the adaptive immune system via depletion of naturally occurring regulatory CD4+CD25+ cells. J Neurobiol 66: 552-563.

Corriveau RA, Huh GS, Shatz CJ. 1998. Regulation of class I MHC gene expression in the developing and mature CNS by neural activity. Neuron 21: $505-520$.

Dantzer R, Konsman JP, Bluthe RM, Kelley KW. 2000. Neural and humoral pathways of communication from the immune system to the brain: Parallel or convergent? Auton Neurosci 85: 60-65.

Dantzer R, O'Connor JC, Freund GG, Johnson RW, Kelley KW. 2008. From inflammation to sickness and depression: When the immune system subjugates the brain. Nat Rev Neurosci 9: 46-56.

Datwani A, McConnell MJ, Kanold PO, Micheva KD, Busse B, Shamloo M, Smith SJ, Shatz CJ. 2009. Classical MHCI molecules regulate retinogeniculate refinement and limit ocular dominance plasticity. Neuron 64: 463-470.

Denes A, Ferenczi S, Kovacs KJ. 2011. Systemic inflammatory challenges compromise survival after experimental stroke via augmenting brain inflammation, blood-brain barrier damage and brain oedema independently of infarct size. J Neuroinflammation 8: 164 .

Derecki NC, Cardani AN, Yang CH, Quinnies KM, Crihfield A, Lynch KR, Kipnis J. 2010. Regulation of learning and memory by meningeal immunity: A key role for IL-4. J Exp Med 207: 1067-1080.

Diaz Heijtz R, Wang S, Anuar F, Qian Y, Björkholm B, Samuelsson A, Hibberd M, Forssberg H, Pettersson S. 2011. Normal gut microbiota modulates brain development and behavior. Proc Natl Acad Sci 108: 3047-3052.

Dummer W, Niethammer AG, Baccala R, Lawson BR, Wagner N, Reisfeld RA, Theofilopoulos AN. 2002. T cell homeostatic proliferation elicits effective antitumor autoimmunity. J Clin Invest 110: 185-192.

Gabay E, Wolf G, Shavit Y, Yirmiya R, Tal M. 2011. Chronic blockade of interleukin-1 (IL-1) prevents and attenuates neuropathic pain behavior and spontaneous ectopic neuronal activity following nerve injury. Eur J Pain 15: 242-248.

Gadani SP, Cronk JC, Norris GT, Kipnis J. 2012. IL-4 in the brain: A cytokine to remember. J Immunol 189: 4213-4219.

Ganea D, Gonzalez-Rey E, Delgado M. 2006. A novel mechanism for immunosuppression: From neuropeptides to regulatory T cells. J Neuroimmune Pharmacol 1: 400-409.

Gautier EL, Shay T, Miller J, Greter M, Jakubzick C, Ivanov S, Helft J, Chow A, Elpek KG, Gordonov S, et al. 2012. Gene-expression profiles and transcriptional regulatory pathways that underlie the identity and diversity of mouse tissue macrophages. Nat Immunol 13: $1118-1128$.

Ginhoux F, Greter M, Leboeuf M, Nandi S, See P, Gokhan S, Mehler MF, Conway SJ, Ng LG, Stanley ER, et al. 2010. Fate mapping analysis reveals that adult microglia derive from primitive macrophages. Science 330: $841-845$.

Godbout JP, Moreau M, Lestage J, Chen J, Sparkman NL, O'Connor J, Castanon N, Kelley KW, Dantzer R, Johnson RW. 2008. Aging exacerbates depressive-like behavior in mice in response to activation of the peripheral innate immune system. Neuropsychopharmacology 33: 2341-2351.

Goddard CA, Butts DA, Shatz CJ. 2007. Regulation of CNS synapses by neuronal MHC class I. Proc Natl Acad Sci 104: 6828-6833.

Goshen I, Yirmiya R. 2009. Interleukin-1 (IL-1): A central regulator of stress responses. Front Neuroendocrinol 30: 30-45.

Goshen I, Kreisel T, Ounallah-Saad H, Renbaum P, Zalzstein Y, Ben-Hur T, Levy-Lahad E, Yirmiya R. 2007. A dual role for interleukin-1 in hippocampal-dependent memory processes. Psychoneuroendocrinology 32: $1106-1115$.

Harrison JK, Barber CM, Lynch KR. 1994. cDNA cloning of a G-protein-coupled receptor expressed in rat spinal cord and brain related to chemokine receptors. Neurosci Lett 169: 85-89.

Hooper L, Littman D, Macpherson A. 2012. Interactions between the microbiota and the immune system. Science 336: 1268-1273.

Hoshiko M, Arnoux I, Avignone E, Yamamoto N, Audinat E. 2012. Deficiency of the microglial receptor CX3CR1 impairs postnatal functional development of thalamocortical synapses in the barrel cortex. J Neurosci 32: 15106-15111.

Huang Y, Henry CJ, Dantzer R, Johnson RW, Godbout JP. 2008. Exaggerated sickness behavior and brain proinflammatory cytokine expression in aged mice in response to intracerebroventricular lipopolysaccharide. Neurobiol Aging 29: 1744-1753.

Huh GS, Boulanger LM, Du H, Riquelme PA, Brotz TM, Shatz CJ. 2000. Functional requirement for class I MHC in CNS development and plasticity. Science 290: 2155-2159.

Ikegaya Y, Delcroix I, Iwakura Y, Matsuki N, Nishiyama N. 2003. Interleukin-1 $\beta$ abrogates long-term depression of hippocampal CA1 synaptic transmission. Synapse 47: 54-57.

Iosif RE, Ekdahl CT, Ahlenius H, Pronk CJ, Bonde S, Kokaia Z, Jacobsen SE, Lindvall O. 2006. Tumor necrosis factor receptor 1 is a negative regulator of progenitor proliferation in adult hippocampal neurogenesis. J Neurosci 26: 9703-9712.

Kaneko M, Stellwagen D, Malenka RC, Stryker MP. 2008. Tumor necrosis factor- $\alpha$ mediates one component of competitive, experience-dependent plasticity in developing visual cortex. Neuron 58: $673-680$.

Katayama Y, Becker DP, Tamura T, Hovda DA. 1990. Massive increases in extracellular potassium and the indiscriminate release of glutamate following concussive brain injury. J Neurosurg 73: 889-900.

Kelley KW, Bluthe RM, Dantzer R, Zhou JH, Shen WH, Johnson RW, Broussard SR. 2003. Cytokine-induced sickness behavior. Brain Behav Immun 17 (Suppl 1): S112-S118.

Kipnis J, Cohen H, Cardon M, Ziv Y, Schwartz M. 2004. T cell deficiency leads to cognitive dysfunction: Implications for therapeutic vaccination for schizophrenia and other psychiatric conditions. Proc Natl Acad Sci 101: 8180-8185.

Kipnis J, Derecki NC, Yang C, Scrable H. 2008. Immunity and cognition: What do age-related dementia, HIV-dementia and "chemo-brain" have in common? Trends Immunol 29: 455-463.

Kipnis J, Gadani S, Derecki NC. 2012. Pro-cognitive properties of T cells. Nat Rev Immunol 12: 663-669.

Kohman RA, Rhodes JS. 2013. Neurogenesis, inflammation and behavior. Brain Behav Immun 27: 22-32.

Kong W, Yen JH, Ganea D. 2010. Docosahexaenoic acid prevents dendritic cell maturation, inhibits antigen-specific Th1/Th17 differentiation and suppresses experimental autoimmune encephalomyelitis. Brain Behav Immun.

Koval KJ, Aharonoff GB, Schwartz MC, Alpert S, Cohen G, McShinawy A, Zuckerman JD. 1997. Pubic rami fracture: A benign pelvic injury? J Orthop Trauma 11: 7-9.

Levite M. 2008. Neurotransmitters activate T-cells and elicit crucial functions via neurotransmitter receptors. Curr Opin Pharmacol 8: $460-471$.

Lewitus GM, Schwartz M. 2009. Behavioral immunization: Immunity to self-antigens contributes to psychological stress resilience. Mol Psychiatry 14: 532-536.

Lucin KM, Wyss-Coray T. 2009. Immune activation in brain aging and neurodegeneration: Too much or too little? Neuron 64: $110-122$

Marin-Teva JL, Dusart I, Colin C, Gervais A, van Rooijen N, Mallat M. 2004. Microglia promote the death of developing Purkinje cells. Neuron 41: $535-547$

Matsumoto Y, Yamaguchi T, Watanabe S, Yamamoto T. 2004. Involvement of arachidonic acid cascade in working memory impairment induced by interleukin-1 ß. Neuropharmacology 46: 1195-1200.

McAllister AK, van de Water J. 2009. Breaking boundaries in neuralimmune interactions. Neuron 64: 9-12.

McConnell MJ, Huang YH, Datwani A, Shatz CJ. 2009. H2-K(b) and H2-D(b) regulate cerebellar long-term depression and limit motor learning. Proc Natl Acad Sci 106: 6784-6789.

McCusker RH, Kelley KW. 2013. Immune-neural connections: How the immune system's response to infectious agents influences behavior. J Exp Biol 216: 84-98.

McGowan PO, Hope TA, Meck WH, Kelsoe G, Williams CL. 2011. Impaired social recognition memory in recombination activating gene 1-deficient mice. Brain Res 1383: 187-195.

Mombaerts P, Iacomini J, Johnson RS, Herrup K, Tonegawa S, Papaioannou VE. 1992. RAG-1-deficient mice have no mature B and T lymphocytes. Cell 68: 869-877.

Moore AH, Wu M, Shaftel SS, Graham KA, O'Banion MK. 2009. Sustained expression of interleukin- $1 \beta$ in mouse hippocampus impairs spatial memory. Neuroscience 164: 1484-1495.

Nautiyal KM, Ribeiro AC, Pfaff DW, Silver R. 2008. Brain mast cells link the immune system to anxiety-like behavior. Proc Natl Acad Sci 105: 18053-18057.

Nautiyal KM, Dailey CA, Jahn JL, Rodriquez E, Son NH, Sweedler JV, Silver R. 2012. Serotonin of mast cell origin contributes to hippocampal function. Eur J Neurosci 36: 2347-2359. 
Nimmerjahn A, Kirchhoff F, Helmchen F. 2005. Resting microglial cells are highly dynamic surveillants of brain parenchyma in vivo. Science 308: 1314-1318.

O'Connor JC, Andre C, Wang Y, Lawson MA, Szegedi SS, Lestage J, Castanon N, Kelley KW, Dantzer R. 2009. Interferon- $\gamma$ and tumor necrosis factor- $\alpha$ mediate the upregulation of indoleamine 2,3-dioxygenase and the induction of depressive-like behavior in mice in response to bacillus Calmette-Guerin. J Neurosci 29: 4200-4209.

Okun E, Griffioen K, Barak B, Roberts NJ, Castro K, Pita MA, Cheng A, Mughal MR, Wan R, Ashery U, et al. 2010. Toll-like receptor 3 inhibits memory retention and constrains adult hippocampal neurogenesis. Proc Natl Acad Sci 107: 15625-15630.

Okun E, Griffioen KJ, Mattson MP. 2011. Toll-like receptor signaling in neural plasticity and disease. Trends Neurosci 34: 269-281

Paolicelli RC, Bolasco G, Pagani F, Maggi L, Scianni M, Panzanelli P, Giustetto M, Ferreira TA, Guiducci E, Dumas L, et al. 2011. Synaptic pruning by microglia is necessary for normal brain development. Science 333: $1456-1458$.

Patterson PH. 2012. Maternal infection and autism. Brain Behav Immun 26: $393-393$.

Pavlov VA, Tracey KJ. 2012. The vagus nerve and the inflammatory reflexlinking immunity and metabolism. Nat Rev Endocrinol 8: 743-754.

Pocock JM, Kettenmann H. 2007. Neurotransmitter receptors on microglia. Trends Neurosci 30: 527-535.

Radjavi A, Smirnov I, Derecki N, Kipnis J. 2013. Dynamics of the meningeal CD4 T-cell repertoire are defined by the cervical lymph nodes and facilitate cognitive task performance in mice. Mol Psychiatry doi: $10.1038 / \mathrm{mp} .2013 .79$.

Ransohoff RM, Cardona AE. 2010. The myeloid cells of the central nervous system parenchyma. Nature 468: $253-262$.

Rogers JT, Morganti JM, Bachstetter AD, Hudson CE, Peters MM, Grimmig BA, Weeber EJ, Bickford PC, Gemma C. 2011. CX3CR1 deficiency leads to impairment of hippocampal cognitive function and synaptic plasticity. J Neurosci 31: 16241-16250.

Rolls A, Shechter R, London A, Ziv Y, Ronen A, Levy R, Schwartz M. 2007. Toll-like receptors modulate adult hippocampal neurogenesis. Nat Cell Biol 9: 1081-1088

Ron-Harel N, Segev Y, Lewitus GM, Cardon M, Ziv Y, Netanely D, Jacob-Hirsch J, Amariglio N, Rechavi G, Domany E, et al. 2008. Age-dependent spatial memory loss can be partially restored by immune activation. Rejuvenation Res 11: 903-913.

Ross FM, Allan SM, Rothwell NJ, Verkhratsky A. 2003. A dual role for interleukin-1 in LTP in mouse hippocampal slices. J Neuroimmunol 144: 61-67.

Schafer DP, Lehrman EK, Kautzman AG, Koyama R, Mardinly AR, Yamasaki R, Ransohoff RM, Greenberg ME, Barres BA, Stevens B. 2012. Microglia sculpt postnatal neural circuits in an activity and complement-dependent manner. Neuron 74: 691-705.

Schneider H, Pitossi F, Balschun D, Wagner A, del Rey A, Besedovsky HO. 1998. A neuromodulatory role of interleukin-1 $\beta$ in the hippocampus. Proc Natl Acad Sci 95: 7778-7783.

Shechter R, London A, Schwartz M. 2013a. Orchestrated leukocyte recruitment to immune-privileged sites: Absolute barriers versus educational gates. Nat Rev Immunol 13: 206-218.

Shechter R, Miller O, Yovel G, Rosenzweig N, London A, Ruckh J, Kim KW, Klein E, Kalchenko V, Bendel P, et al. 2013b. Recruitment of beneficial
M2 macrophages to injured spinal cord is orchestrated by remote brain choroid plexus. Immunity 38: 555-569.

Sierra A, Encinas JM, Deudero JJ, Chancey JH, Enikolopov G, Overstreet-Wadiche LS, Tsirka SE, Maletic-Savatic M. 2010. Microglia shape adult hippocampal neurogenesis through apoptosis-coupled phagocytosis. Cell Stem Cell 7: 483-495.

Spiegel A, Shivtiel S, Kalinkovich A, Ludin A, Netzer N, Goichberg P, Azaria Y, Resnick I, Hardan I, Ben-Hur H, et al. 2007. Catecholaminergic neurotransmitters regulate migration and repopulation of immature human CD34+ cells through Wnt signaling. Nat Immunol 8: $1123-1131$.

Spulber S, Mateos L, Oprica M, Cedazo-Minguez A, Bartfai T, Winblad B, Schultzberg M. 2009. Impaired long term memory consolidation in transgenic mice overexpressing the human soluble form of IL-1ra in the brain. J Neuroimmunol 208: 46-53.

Steinman L. 2004. Elaborate interactions between the immune and nervous systems. Nat Immunol 5: 575-581.

Stellwagen D, Malenka RC. 2006. Synaptic scaling mediated by glial TNF- $\alpha$. Nature 440: $1054-1059$.

Stevens B, Allen NJ, Vazquez LE, Howell GR, Christopherson KS, Nouri N, Micheva KD, Mehalow AK, Huberman AD, Stafford B, et al. 2007. The classical complement cascade mediates CNS synapse elimination. Cell 131: $1164-1178$.

Syken J, Grandpre T, Kanold PO, Shatz CJ. 2006. PirB restricts ocular-dominance plasticity in visual cortex. Science 313: 1795-1800.

Tremblay ME, Lowery RL, Majewska AK. 2010. Microglial interactions with synapses are modulated by visual experience. PLoS Biology 8: e1000527.

von Bernhardi R, Tichauer JE, Eugenin J. 2010. Aging-dependent changes of microglial cells and their relevance for neurodegenerative disorders. J Neurochem 112: 1099-1114.

Wake H, Moorhouse AJ, Jinno S, Kohsaka S, Nabekura J. 2009. Resting microglia directly monitor the functional state of synapses in vivo and determine the fate of ischemic terminals. J Neurosci 29: 3974-3980.

Wang L, Christophersen C, Sorich M, Gerber J, Angley M, Conlon M. 2012. Elevated fecal short chain fatty acid and ammonia concentrations in children with autism spectrum disorder. Dig Dis SCi 57: 2096-2102.

Wolf G, Livshits D, Beilin B, Yirmiya R, Shavit Y. 2008. Interleukin-1 signaling is required for induction and maintenance of postoperative incisional pain: Genetic and pharmacological studies in mice. Brain Behav Immun 22: 1072-1077.

Wolf SA, Steiner B, Akpinarli A, Kammertoens T, Nassenstein C, Braun A, Blankenstein T, Kempermann G. 2009. CD4-positive T lymphocytes provide a neuroimmunological link in the control of adult hippocampal neurogenesis. J Immunol 182: 3979-3984.

Yirmiya R, Goshen I. 2011. Immune modulation of learning, memory, neural plasticity and neurogenesis. Brain Behav Immun 25: 181-213.

Ziv Y, Ron N, Butovsky O, Landa G, Sudai E, Greenberg N, Cohen H, Kipnis J, Schwartz M. 2006. Immune cells contribute to the maintenance of neurogenesis and spatial learning abilities in adulthood. Nat Neurosci 9: 268-275.

Received March 25, 2013; accepted in revised form July 19, 2013. 


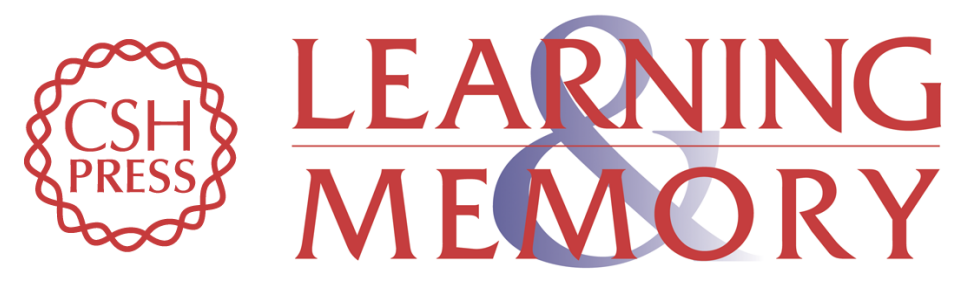

\section{Learning and memory ... and the immune system}

Ioana Marin and Jonathan Kipnis

Learn. Mem. 2013, 20:

Access the most recent version at doi:10.1101//m.028357.112

References This article cites 93 articles, 26 of which can be accessed free at: http://learnmem.cshlp.org/content/20/10/601.full.html\#ref-list-1

Creative This article is distributed exclusively by Cold Spring Harbor Laboratory Press for the Commons License first 12 months after the full-issue publication date (see http://learnmem.cshlp.org/site/misc/terms.xhtml). After 12 months, it is available under a Creative Commons License (Attribution-NonCommercial 3.0 Unported), as described at http://creativecommons.org/licenses/by-nc/3.0/.

Email Alerting Receive free email alerts when new articles cite this article - sign up in the box at the Service top right corner of the article or click here. 